\title{
Information literacy for higher education institutions in Nigeria and Tanzania: efforts and prospects for educational reform in teaching and learning
}

\section{Vicki Lawal, Peter Underwood, Mugyabuso Lwehabura and Christine Stilwell}

Vicki Lawal

Information Studies Programme

University of KwaZulu-Natal, Pietermaritzburg

209539667@ukzn.ac.za

Peter Underwood

Centre for Information Literacy and Department of Library and Information Studies, University of Cape Town

Peter.Underwood@uct.ac.za

Mugyabuso Lwehabura

Library

Sokoine University of Agriculture, Tanzania

lwehabura@suanet.ac.tz

Christine Stilwell

Information Studies

University of KwaZulu-Natal, Pietermaritzburg

stilwell@ukzn.ac.za

\begin{abstract}
This article reviews efforts made by higher education institutions in Nigeria and Tanzania in transforming student learning through information literacy (IL). It examines the need for higher education institutions in the two countries to create the necessary foundations for strengthening information literacy programmes as a strategy for ensuring viable transformation in teaching and learning. The paper is based on a review of related literature and observations
\end{abstract}


drawn from working experiences in higher education institutions in both countries. It examines some of the meaningful educational transformations taking place in higher education institutions in Nigeria and Tanzania and makes recommendations for better standards to be developed in terms of curriculum structure and design, teaching methods, outcome assessment and a review of institutional policies and goals in order to encourage active teaching and learning.

\section{Introduction}

Changes and demands in the global economy have compelled higher education institutions to reconsider the nature and composition of educational curricula. Undergraduate teaching and learning in particular has been the subject of critical scrutiny with focus on issues of curriculum design, the development of critical thinking abilities and lifelong learning in the educational experience (McFadden and Hostetler 1995: 221). Concerns among academic librarians in the debate are based on the understanding that the rapid proliferation of a variety of complex and sophisticated electronic retrieval systems and knowledge and skills for handling and managing information in various formats, raise important questions about the intelligibility and utility of these resources to undergraduate students (Pask and Snow 1995: 306). This has created the need to prepare students for the information age through information literacy by addressing problems in knowledge and skills deficiency in student learning. This article seeks to highlight some of the efforts made in information literacy (IL) education aimed at promoting teaching and learning in Nigeria and Tanzania. It is anticipated that a literature review of the progress made so far will contribute to the attempts aimed at reforming student learning through IL.

The qualities of an information literate person as outlined in the Association of College and Research Libraries (ACRL) document on Information Literacy Competency Standards for Higher Education (2000) are particularly cogent principles that are useful for academic libraries and appropriate as a conceptual framework for learning communities especially with regard to developing competences and improving quality in student learning. This is because they provide guidance for developing competencies and improving the quality of student learning through outcomes-based education. The American Library Association (ALA) and the Association of College and Research Libraries (ACRL) have actively promoted IL as necessary for an informed society in general and especially for students in higher education institutions (Saunders 2009: 99). 


\section{Information literacy and student learning}

Student learning processes encompass activities which include thinking, evaluation and problem solving. These learning processes incorporate changes in knowledge, understanding, skills and attitudes brought about by experience and reflection upon the experience (Brown, Bull and Pendlebury 1997: 21). The challenge to prepare students for their role in the knowledge economy is reflective of the efforts towards promoting lifelong learning and other developmental goals. The concept of lifelong learning in IL connotes the inculcation of life skills to enable the learner to adapt to the constantly changing information society. Similarly, the context of self-directed learning implies an independent pursuit by the learner in a continuous search for knowledge by which he or she is capable of self motivation and can critically assess or analyse a given situation and apply appropriate information for problem-solving. Students are central to the learning process and the responsibility of educational institutions in ensuring that opportunities are created for students to acquire the needed competences is germane to developing lifelong learning abilities (Behrens 1995: 254). The need for educational reform and re-structuring of the learning process forms an important premise for the success of IL programmes in higher education institutions. This need is indicated by findings from various studies which have supported the need for reform in the educational process (Lwehabura 2007: 315, Kuhn 2008: 472 and Lawal 2009:175). This recognition constitutes an important ingredient for the success of IL in higher education institutions. Dakshinamurti and Horne (2006: 1) and Virkus, (2003) have also argued the case for IL as an important goal for higher education institutions in the United States of America and Europe. A measure of success has been achieved in these regions through the application of IL standards. However, despite the importance and measure of success recorded in these regions, the level of acceptance and implementation of IL programmes in academic libraries in African countries is not yet widespread.

The shift in development from labour intensive economies to information intensive economies and changes in educational orientation require a range of intellectual processes and skills that encompass lifelong learning, communication skills and knowledge management. According to Candy (2002), learning contexts and the range of skills that are required to enable people to succeed in work places and daily activities have become too complex and that IL skills have become paramount in this regard. In today's technologically advanced society in which information has acquired a central role in delineating 
many of the world's economic, cultural and political aspects, the importance of IL cannot be over emphasized (Stilwell, Leach and Burton 2001: v).

Information literacy is important for reinforcing student centred learning approaches because it supports resource based learning. It is from this point of view that Van Vuren and Henning (2001: 81) contend that student centred resource based learning cannot be successful if students have not acquired effective information handling skills. Changes in the formats of educational resources, such as digitisation of scholarly publications and the growth in online delivery and other electronic learning resources, requires various skills, fluency with information technology and learning skills that are beyond rote learning (Bundy 2001). In many academic institutions changes in the educational philosophy indicated by a shift from teacher-centred teaching to a student learning centred has become standard practice (Sparrow, Sparrow and Swan 2000). Central to student-centred learning is an emphasis on critical thinking and independent learning. The student centred approach empowers students to be more responsible for their learning by providing them with the ability for deeper learning and a higher degree of flexibility in lifelong learning (Motschnig-Pitrik and Holzinger 2002).

The significance of IL lies in its potential to encourage deep, rather than surface learning and transform dependent learners into independent, self directed lifelong learners (Bruce 2002). IL also supports, promotes and enhances teaching and research and creates a learning culture that can produce graduates with a capacity and a desire for lifelong learning in a rapidly changing, complex and information abundant environment. Bundy (1998) also accentuates the point that through IL the following qualities can be inculcated:

- Ability to operate effectively at sufficient information depth to begin a professional practice.

- Preparedness for lifelong learning in pursuit of personal development and excellence in professional practice.

- Effectiveness in problem solving through application of logical, critical and creative thinking.

- Working autonomously and collaboratively as a professional.

In general as pointed out by Bundy (1998) the complex nature of the information environment underscores the importance of IL. 


\section{Information literacy education in Nigeria}

Higher education institutions are among the fastest growing sectors of the Nigerian educational system. The past two decades particularly have witnessed a proliferation of institutions of higher education in the country. Currently, there are over 35 universities including federal, state and privately owned universities. There are also a number of polytechnics, teacher training colleges and other specialised institutions of learning (Okuwa 2004: 4; Saint, Hartnett and Strassner 2003: 7). The development of IL in Nigeria, as with other countries, is based on the premise that IL skills are vital tools needed to function in the information age. Information literacy activities in higher education institutions in Nigeria have existed in the guise of various user education programmes such as library instruction, library orientation and bibliographic instruction (Idiodi 2005: 226). The method of instruction has been on a one-onone basis and the use of manuals and guides usually aimed at familiarising students with library facilities and services. These user education programmes were eventually integrated into the General Studies course which is offered as a compulsory credit-earning course by some universities. In most cases, the components of the course included library and reading skills with limited emphasis on information and communication technology (ICT) (Rasaki 2008: $1)$.

In recent years, there has been increasing interest among educators and academic librarians in Nigeria on the need to establish core IL curricula in universities as a way of facilitating skills development and imparting basic knowledge in student learning through IL. Baro and Fyneman (2009) investigated undergraduate students' level of awareness of information sources available at the Niger Delta University. Findings from the study indicated that over $75 \%$ of the students were familiar with available resources, both print and electronic and their use for research. A test of their search strategies revealed that they employed different methods including following through from references and use of the catalogue to retrieve information. Results also indicated that male students were more digitally literate, utilised internet facilities and CD-ROMS provided in the university library and employed different search engines more than the female students.

Lawal (2009), in a comparative study of the IL skills of third year undergraduate law students of the University of Cape Town (UCT), South Africa and University of Jos (UJ), Nigeria, investigated the relevance of IL in the context of legal education as it affects issues of the conduct of the legal 
research skills of undergraduate students and the need for its integration into the curriculum of legal education. The study explored the particular structure of legal information resources and the distinctive ways in which legal information is both evaluated and used among undergraduate law students. Findings suggested deficiencies in current practices in the teaching methods of IL at the University of Jos with further implications for issues of transferability of acquired skills to the workplace. While $29 \%$ of UCT law students indicated they had received IL training in the first two years of studies, $13 \%$ of UJ students indicated they had received no training at all.

Another study by Issa, Amusan and Daura (2009) sought to determine the effect of information literacy skills training on the use of electronic resources by students, as well as the nature of information literacy courses offered at the University of Ilorin. Outcomes from the study showed that the information literacy skills of the students are yet to meet the ACRL standards. The authors noted that even though most students were aware of the availability of e-library resources, the poor level of skills prevented them from effectively using these resources. Recommendations from the study stressed the need for greater collaboration between librarians and faculty to improve the provision and level of information literacy, and the adoption of the ACRL (2000) "Information literacy competency standards for higher education" as an institutional policy in order for the desired outcomes to be achieved.

Against this background, it is noted that the efforts towards reform in student teaching and learning in higher education institutions in Nigeria are being propelled by the need to empower students to meet the challenges of a knowledge-based economy by establishing better standards through IL programmes. This need for reform is driven by the increasing demand for jobrelated skills. The above studies have also shown that most graduates in Nigeria tend to exhibit inadequate attributes of IL skills in the workplace. This has further highlighted the need for graduate students to be equipped with transferable skills applicable to different contexts in the workplace (Rasaki 2008: 5). However, it is noted that despite the growing commitment by academic libraries to integrating IL into academic programmes in Nigerian universities, there is a need to develop appropriate guidelines for teaching and assessing students' IL skills in higher education institutions. Specifically, a paradigm shift is needed in the teaching of IL instruction from a focus on what is being taught and the testing of skills, to how standards can be developed to improve student learning, especially at the pedagogic level. Consequently, recommendations from some of these studies have pointed to the need for a 
review of educational goals in higher education institutions in Nigeria in order to determine how IL standards as outlined in the ACRL (1998) "Information literacy competency standards for student learning", can be adopted to improve learning and enhance effectiveness in teaching methods (Idiodi 2005: 229; Issa, Amusan and Daura 2009; Rasaki, 2008: 6; Lawal, 2009: 177; Amalahu, Oluwasina and Laoye, 2009: 6).

\section{Information literacy education in Tanzania}

Tanzania had only one higher education institution at independence in 1961 the University College of Dar-Es-Salaam. Since then the educational system has grown to over 140 tertiary training institutions of which more than 20 are higher education institutions (Ministry of Science Technology and Higher Education, Tanzania, 1999). As of March 2010, Tanzania had 32 universities and university colleges that are owned by both the public and private sectors. Of the universities, eight are publicly owned while 11 are privately owned. On the other hand there are three public and 10 private university colleges. In terms of age, 12 universities (37.5\%) were established between 1970 and 1998, while 20 $(62.5 \%)$ were established between 2000 and 2008. These institutions which offer a range of degree programmes in social sciences, applied sciences and humanities have a total of 118,680 students $(84,622$ in public and 34,068 in private institutions) as well as 3,499 academic staff $(2,531$ in public and 968 in private) (Ministry of Education and Vocational Training 2010). Information literacy activities in higher education institutions in Tanzania are relatively new, although as in other countries, librarians have been guiding library users using various rubrics such as user education, library instruction, library orientation and bibliographic instruction (Lwehabura and Stilwell 2008: 183).

In recent years however, interest in IL and its contribution to teaching and learning has emerged and a number of studies in IL issues have been conducted. Such studies include those by Wema and Hepworth (2007); Lwehabura and Stilwell (2008); Lwehabura (2008) and Chilimo (2008). Currently, higher education institutions in Tanzania, universities in particular, practice various forms of programmes. Methods used for teaching IL include library orientation, hands-on practice, seminar presentations, leaflets and information posted on web pages to guide students. Information search skills, use of various library facilities, information evaluation, and use of various sources of information and citation and referencing form core aspects taught as part of IL instruction (Lwehabura 2008: 161). However, in terms of the effectiveness of the teaching methods and the general conditions in which delivery occurs, findings from 
studies indicate a number of areas that need some attention in order to create more effective interventions toward transmitting expected knowledge and skills. According to Lwehabura and Stilwell (2008: 183), these include:

- Lack of an IL policy.

- Lack of a proactive disposition among librarians.

- Lack of partnerships between librarians and teaching staff to mainstream IL.

- Inadequacy in the availability of information resources and librarians.

- Unwillingness among students to take IL courses.

Other challenges as identified by Chilimo (2008: 77) include:

- Inadequate time allowed for students to attend IL programmes.

- Lack of enthusiasm among students, staff and administrators towards IL education.

Studies conducted in Tanzania also identified some information skills deficiencies among students that include a lack of skills in:

- the use of electronic resources

- information evaluation, including internet information

- computer use.

These outcomes are similar to those found in studies undertaken in Nigeria. In his study, Lwehabura (2007) found that $74.7 \%$ of the 664 students studied were facing difficulties in comprehending, selecting and using information from various formats. Of the students, $90.4 \%$ indicated that they needed training in the use of online databases while $91.3 \%$ indicated the need for training in the use of the Internet. The study found further that students had as their first priority the need for training in the following areas: searching for information from electronic sources $(63.8 \%)$, knowledge about using electronic sources $(60.6 \%)$, topic analysis $(44.9 \%)$, and formulation of search strategy (38.6\%).

However, some improvements towards effective IL programmes delivery have been achieved as some of the identified challenges have been tackled. Individual librarians in different institutions are educating other university community members especially members of the teaching staff on the importance and role of IL in the entire teaching and learning process. As a result there have been numerous requests from teaching staff for special IL sessions for both under- and postgraduate students enrolled in various courses. This is a clear indication of the recognition by the lecturers of the importance of students gaining IL skills. Likewise, students have started to show a positive attitude 
towards IL as increasing numbers of them are registering for voluntary IL sessions whenever they are announced by librarians. The availability of resources such as computers and other electronic resources is also increasing. Computer use skills among students are also improving, not only because higher education institutions are introducing courses that are directly linked to computer use and application but also because a number of secondary schools have introduced computer classes (Hare 2007). As a result a number of students join higher learning institutions with basic computer knowledge and skills.

A good example of IL being integrated into the curriculum is found at Sokoine University of Agriculture (SUA). Following a review of all undergraduate courses endorsed by Sokoine University Senate and Council in 2008, beginning in the 2010/2011 academic year, a two credit course known as Computer Applications (CIT 200) will be compulsory for all undergraduate students (Sokoine University of Agriculture 2008a and 2008b). The course also involves other aspects of IL (see below).This will make SUA the only higher learning institution in Tanzania to provide a course on IL that is credit earning and compulsory to all students.

The course objectives are to enable students to:

- Analyse, interpret and present numerical data using spreadsheet software.

- Describe concepts of relational database management systems.

- Design and develop database of systems relating to their field of specialisation.

- Determine information needs and information sources.

- Locate, retrieve and evaluate relevant information from electronic and non electronic format.

- Demonstrate understanding of ethical and legal issues surrounding information use.

The challenge for SUA will be to monitor and evaluate the course's progress and its general outcomes in terms of students' skills so that it can be continually improved.

\section{Areas for needed reform in information literacy education}

The major challenge affecting IL development in both Nigeria and Tanzania is the absence of an IL policy at the national level. In the United States, Australia, and some European countries, IL is strongly advocated by their respective 
governments, institutions of higher learning and professional associations such as the ALA, Society of College, National and University Libraries (SCONUL) in the United Kingdom, and the Australian and New Zealand Institute for Information Literacy (ANZIL). In Nigeria and Tanzania however, IL policies exist only at institutional levels and this problem of the lack of a national policy has contributed to the difficulties experienced with regard to implementation of IL programmes. Under the United Nations Educational Scientific and Cultural Organisation's (UNESCO) two global programmes 'Education for all' and 'Information for all', IL is categorised as a critical dimension for achieving the higher level goals for 'Education for all' and 'Information for all' (Zwimpfer 2006). However, despite this recognition, little weight has been given to IL in these countries as an important vehicle for enhancing teaching and learning in higher education institutions and a vital tool for encouraging and developing an informed citizenry in a democratic society.

Educational reforms are often focused on renewal, transformation or change, the aim of which is to bring about improvement or progress in the quality and standard of learning and teaching. Expectations in the efforts towards reform include the challenge to implement changes that relate to issues of standardisation, the development of competencies and the adoption of effective teaching methods that address diverse learning needs (Schweisfurth 2002: 13). It is noted however, that despite the growing commitment of academic libraries to integrating IL into the curriculum in Nigeria and Tanzania, there is a need to develop appropriate guidelines for teaching and assessing students' IL skills in higher education institutions. Specifically, a paradigm shift is needed in the teaching of IL instruction from a focus on what is being taught and the testing of skills, to how standards can be developed to improve student learning especially at the pedagogic level. Effective student learning should be the goal of IL efforts. However in order to meet this challenge, quality instructional design and active learning strategies are key components that can lead to building vigorous IL programmes. For the purpose of transforming our educational systems, it is important that the focus should be on programmes of IL education that are beyond the single session method and to determine how these programmes can be better articulated through comprehensive strategy formulated at both national and institutional levels in order to meet students learning needs. The following are some important areas of consideration:

Curriculum structure and design: The design of the curriculum should be informed by IL standards which will also identify the educational objectives of the programme. Research findings on programmes of IL in Nigeria, Tanzania 
and other countries have consistently pointed to the need for IL course integration in the academic curriculum. The relevance of IL is best exemplified within a subject specific context. Conceptions of IL within a disciplinary context helps promote an attitude of critical inquiry to the learning process and provide a framework by which needed skills can be integrated into the curriculum. By teaching the conceptual models for handling information through an integrated and incremental approach, students are provided with a broad context for understanding the different forms, sources and structures of information which also ensures the transferability of acquired skills to the workplace environment (Whitehead and Quinlan 2002: 13; Lwehabura 2007: 321; Webber and Johnston 2000: 385; Baro and Fyneman 2009: 672; Grafstein, 2002: 200). The ACRL "Information Literacy Competency Standards for Student Learning" (1998) provide a framework for determining student growth levels from programmes of IL education and helps in identifying specific areas where students are deficient in skills. The standards are student-centred and can be aligned to institutional and disciplinary learning goals which can be integrated into the integrated into the content, structure and sequence of an academic curriculum (Knight 2002: 15-16). The ACRL competency standards consist of three broad categories: IL standards, independent learning standards and social responsibility standards, with nine main standards and 29 indicators.

Methods of teaching and learning: The popularity of the constructivistcognitive methods of learning such as resource-based learning, active learning, problem-based learning, brain-based learning and so on, have challenged educators to re-think some basic assumptions as to how learning occurs in students (Warmkessel and McCade 1997: 81). Such process oriented learning methods are aimed at balancing the process and content of learning in order to align differences between the curriculum and the actual student experience in view of the overwhelming explosion of the knowledge base. Some criticisms have been raised regarding pedagogical methods used in sub-Saharan Africa education systems. Among the criticisms raised is the application of rigid teaching approaches that are centred on memorisation and restitution thus failing to encourage learners to develop their intelligence and creativity and instilling a good sense of innovation and training for research activities (United Nations University 2009). Student-centred learning processes are specifically enhanced by problem-based approaches; they promote deeper learning and help to provide an estimate of progress made in various aspects of teaching and learning. Active learning processes enable students to construct knowledge and make meaning from learned experiences (Brown, Bull and Pendlebury 1997: 26). 
Outcome assessment: Assessment provides an effective way of measuring the progress of an educational system and appraising institutional goals and objectives. It is a vehicle for educational reform and helps to show the connection between teaching and learning which would further inform the development of programmes of curricula that reflect progress in IL (Beets 2007: 579). Outcome assessment and evaluation of IL initiatives through established standards of measurement provide evidence of institutional commitment to developing the required competency skills and highlights the role of the library and academic faculty in student learning and development and provide evidence of the need for IL programmes (Oakleaf 2008: 233-234).

Assessment of IL skills should be multi-dimensional, dealing with cognitive, affective and learning skills. It may be formative, summative, qualitative, quantitative or other forms, the importance being to determine the strategic value of information use and to foster ongoing improvement for the user or provider of instruction (Kiondo, Katunzi and Mollel 2005: 196). Currently there are no nationally agreed upon standards in information literacy in higher education institutions in Nigeria and Tanzania to deal with issues of outcome assessment and identifying problems of deficiency in students' IL skills (Issa, Amusan and Daura, 2009; Lawal 2009: 177).

Librarian/faculty collaboration: Making IL an integral part of a university's educational strategy cannot be achieved by librarians alone. The key to promoting student learning in higher education institutions requires collaborative partnership between librarians and the teaching faculty (Doskatsch 2003). Issues of collaboration have tended to create conflict between librarians and faculty especially with regards to issues of curriculum planning and design (Lindstrom and Shonrock 2006: 18, 19). Due to the important role IL plays in enhancing the curricula and educational mission of an institution, it is important that IL programmes are executed as part of the educational strategy of the institution rather than solely as a library exercise (Snavely and Cooper 1997: 57; Issa, Amusan and Daura 2009). In this regard collaboration among professional library staff, teaching staff, and university administrators in fostering IL across the curriculum as well as inculcating IL knowledge and skills among students is inevitable (Lwehabura and Stilwell 2008: 189).

Governmental and institutional policies: Recommendations from studies in IL in Nigeria and Tanzania have pointed to the need to develop an institution-wide policy which recognises the value of IL as an educational objective that can be systematically covered in the academic curricula (Idiodi 2005: 229; Lwehabura 
2007: 288). However, this can only be achieved through a commitment to implementation by all stakeholders. Executing IL programmes without governmental or institutional support does not often produce the desired outcomes. Implementation efforts in South Africa and other countries have shown that governmental policy on the need to facilitate and accelerate economic, educational, and social development provided considerable impetus to development of ICTs and the development of an information society (De Jager and Nassimbeni 2002: 169; Underwood 2002: 10). A specific area for involvement by the government in Nigeria and Tanzania in this regard is the provision of a formidable financial base for the implementation of IL programmes particularly with respect to staff training and infrastructural development.

\section{Conclusion}

The challenges of globalisation and other technological advances demand that students are empowered with the essential information skills that enable them to function in a knowledge driven economy. Information literacy education offers higher education institutions a broad approach by which students can be educated to understand the importance of information and to have the competence to manage information in ways that contribute to a higher level of literacy and lifelong learning (Somi and De Jager 2005: 260). The literature on IL in higher education institutions in Nigeria and Tanzania is evolving. A review of the efforts made towards implementation of IL in the past few years reveal that experiences of challenges to implementation bear some similarities with other educational institutions in Africa particularly with respect to such problems as inadequately skilled librarians, lack of national and educational policies, poor funding, lack of an effective method of evaluation of IL practices and poor collaboration between librarians and faculty (Ojedokun and Lumande 2005: 123; Kavulya 2003: 222; Viljoen 2005: 112; Sayed 1998: 6-7; Lwehabura and Stilwell, 2008: 185 ). The efforts towards reforming student learning are ongoing which requires a re-thinking of the role of education in nation building (Obanya 1998: 619). The challenges facing IL implementation at higher education institutions in Nigeria and Tanzania also offer opportunities for reform in the educational system in terms of establishing benchmarks from evidences of best practices from other countries and in particular African countries such as South Africa and Botswana where significant progress has been made in IL implementation. For the desired outcomes to be achieved 
however, general policy issues outlining standards that fit the objectives of IL in higher education institutions in Nigeria and Tanzania must be established to ensure lasting reforms.

\section{References}

Amalahu, C., Oluwasina, O.O.E., and Laoye, O.A. 2009. Higher education and information literacy: a case study of Tai Solarin University of Education. Library philosophy and practice.

http://digitalcommons.unl.edu/cgi/viewcontent.cgi?article=1245andcontext=libp hilprac Accessed 20 June 2010.

Association of College and Research Libraries. 1998. Information literacy standards for student learning.

http://edweb.tusd.k12.az.us/uttelib/Information\%20Literacy\%20Standards\%20f or\%20Student\%20Learning.htm. Accessed 22 June 2010.

Association of College and Research Libraries. 2000. Information literacy competency standards for higher education.

www.ala.org/acrl/ilcomstan.htm.58k Accessed 11 June 2010.

Baro, E.E. and Fyneman, B. 2009. Information literacy among undergraduate students in the Niger Delta University. The electronic library 27 (4): 659-675.

Beets, P.A.D. 2007. (Re)positioning assessment in higher education: the case of geography in South Africa. South African journal of higher education 21 (4): 577-584.

Behrens, S.J. 1995. Lifelong learning in the new education and training system. Mousaion 13 (1/2): 251-263.

Brown, G., Bull, J., and Pendlebury, M. 1997. Assessing student learning in higher education. London: Routledge.

Bundy, A. 1998. Information literacy: the key competency for the 21 st Century. Paper presented at the Annual Conference of the International Association of Technological University Libraries, Pretoria, South Africa, 1-5 June, 1998. http://www.library.unisa.edu.au/papers/inlit21.htm. Accessed 9 July 2010.

Bundy, A. 2001. For a clever country: information literacy diffusion in the 21 
century. Paper presented at the First National Round Table on Information Literacy conducted by the Australian Library and Information Association (ALIA), State Library of Victoria, Victoria, 28th February 2001. http://www.library.unisa.edu.au/papers/clever.htm Accessed 9th July 2010.

Candy, P.C. 2002. Lifelong learning and information literacy. White paper prepared for UNESCO, the US National Commission on Libraries and Information Science and the National Forum on Information Literacy for use at the Information Literacy Meeting of Experts, Prague, Czech Republic. http://www.ala.org/acrl/nili/ilitlst.html Accessed 25 June 2010.

Chilimo, W.L. 2008. Training in online search skills at Sokoine University of Agriculture, Tanzania: the use of TEEAL and AGORA Databases. University of Dar-Es-Salaam library journal 10 (1-2): 68-80.

Dakshinamurti, G. and Horne, L. 2006. Integrating information literacy in a first year university course: a case study from Canada. In: Libraries: dynamic engines for the knowledge and information society. Proceedings of 72nd IFLA General Conference and Council, Seoul, Korea, August 20th-24th 2006. http://archive.ifla.org/IV/ifla72/papers/125-Dakshinamurti_Horne-en.pdf Accessed 20 June 2010.

De Jager, K. and Nassimbeni, M. 2002. Institutionalizing information literacy in tertiary education: lessons learnt from South Africa. Library trends 51(1-2): 167-183.

Doskatsch, I. 2003. Perception and perplexities of the faculty-librarian partnership: an Australian perspective. Reference services review 31(2): 111121. http://www.emeraldinsight.com/insight/viewcontentselvlet Accessed 19 June 2010.

Grafstein, A. 2002. A discipline-based approach to information literacy. Journal of academic librarianship 28 (4): 197-204.

Hare, H. 2007. Survey of ICT and education in Africa: Tanzania Country Report-ICT in education in Tanzania. http://www.infodev.org/en/Document.432.pdf Accessed 6 October 2010.

Idiodi, E.A. 2005. Approaches to information literacy acquisition in Nigeria. Library review 54 (4): 223-230. 
Issa, A.O., Amusan, B. and Daura, U.D. 2009. Effects of information literacy skills on the use of e-library resources among students of the University of Ilorin, Kwara State, Nigeria. Library philosophy and practice. http://www.webpages.uidaho.edu/ mbolin/issa-blessing-daura.htm Accessed 5 July 2010.

Kavulya, J.M. 2003. Challenges facing information literacy in Kenya: a case study of selected university libraries in Kenya. Library management 24 (4/5): 216-222.

Kiondo, E., Katunzi, A. and Mollel, E. 2005. Information literacy programmes in Tanzanian academic libraries: the case of University of Dar Es Salaam library. In: Kiondo, E. and Msuya, J. (eds.). User information literacy: case studies from university library programmes in SCANUL - ECS region. UK/Tanzania: INASP, pp 187-215.

Knight, L. 2002. The role of assessment in library user education. Reference services review 30 (1): 15-24.

Kuhn, R. 2008. Designing and assessing the feasibility of an active learning approach to the teaching of legal research. Ph.D. thesis. Pietermaritzburg: University of KwaZulu-Natal.

Lawal, V. 2009. Aspects of information literacy with regards to the use of legal resources: case study of third year undergraduate law students of the University of Cape town, South Africa and University of Jos, Nigeria. Cape Town. M.Phil. University of Cape Town.

Lindstrom, J. and Shonrock, D.D. 2006. Faculty-librarian collaboration to achieve integration of information literacy. Reference and user service quarterly 46 (1): $18-23$.

Lwehabura, M.J.F. 2007. The status and practice of information literacy for teaching and learning in four Tanzanian universities. $\mathrm{PhD}$ thesis. University of KwaZulu-Natal. Pietermaritzburg.

Lwehabura, M.J.F. 2008. Information literacy delivery in Tanzanian Universities: an examination of its effectiveness. African journal of library, archives and information science 18 (2): 157-168. 
Lwehabura, M.J. and Stilwell, C. 2008. Information literacy in Tanzanian universities: challenges and potential opportunities. Journal of librarianship and information science 40 (3): 79 -191.

Lwehabura, M.J.F. 2008. Skills and training needs for use of electronic information resources (EIRs) among students in four Tanzanian universities. University of Dar-Es-Salaam library journal 10 (1-2): 1-21.

McFadden, T.G. and Hostetler, T. (eds.) 1995. Library and undergraduate education: introduction. Library trends 44 (2): 221-236.

Ministry of Education and Vocational Training, Tanzania (MEVT). 2010. Statistics: national. http://www.moe.go.tz/statistics.html. Accessed 8 February 2011.

Ministry of Science Technology and Higher Education, Tanzania (MSTHE). 1999. National higher education policy. Dar-Es-Salaam:

http://www.tanzania.go.tz/policiesf.html Accessed 28 July 2010.

Motschnig-Pitrik, R. and Holzinger, A. 2002. Student-centered teaching meets new media: concept and case study. Educational technology and society 5(4): 160-172.

http://www.pri.univie.ac.at/Publications/2002/Motschnig_IEEE20002_Student Centered_Teaching.pdf Accessed 5 July 2010

Oakleaf, M. 2008. Dangers and opportunities: a conceptual map of information literacy. Portal: libraries and academy 8 (3): 233-253.

Obanya, P. 1998. Patterns of educational reform in Africa. Prospects 28 (4): 619-628.

Ojedokun, A.A. and Lumande, E. 2005. Integration of information literacy skills into a credit-earning programme at the University of Botswana. African journal of library archival and information science 15 (2): 117-124.

Okuwa, O. B 2004. Private returns to higher education in Nigeria. Nairobi: African Economic Research Consortium (AERC). Research paper 139.

Pask, J.M. and Snow, C.E. 1995. Undergraduate instruction and the internet. Library trends 44 (2): 306-317. 
Rasaki, O.E. 2008. A comparative study of credit earning information literacy skills courses in three African universities. Library philosophy and practice December: 1-7. http://www.webpages.uidaho.edu/ mbolin/rasaki.htm Accessed 11 July 2010.

Saint, W., Harnett, T.A., and Strassner, E. 2003. Higher education in Nigeria: a status report. Higher education policy 16: 259-281.

Saunders, L. 2009. The future of information literacy in academic libraries: a Delphi study. Portal: libraries and the academy. 9 (1): 99-114.

Sayed, Y. 1998. The segregated information highway: information literacy in higher education. Cape Town. University of Cape Town Press.

Schweisfurth, M. 2002. Teachers, democratisation and educational reform in Russia and South Africa. Oxford: Symposium Books.

Snavely, L. and Cooper, N. 1997. The information literacy debate. Journal of academic librarianship 23 (1): 9-13.

Sokoine University of Agriculture. 2008a. 106th Council Meeting held on 9/10/2008, Morogoro, Tanzania.

Sokoine University of Agriculture. 2008b. 164th Senate Meeting held on 25/9/2008, Morogoro, Tanzania.

Somi, N. and De Jager, K. 2005. The role of academic libraries in the enhancement of information literacy: a study of Fort Hare Library. South African journal of library and information science 7 (3): 259-267.

Sparrow, L. Sparrow, H. and Swan, P. 2000. Student centred learning: is it possible? Teaching and learning forum.

http://lsn.curtin.edu.au/tlf/tlf2000/sparrow.html Accessed 27 July 2004.

Stilwell, C., Leach, A. and Burton, S. 2001. Introduction. In: Stilwell, C., Leach, A. and Burton, S. (eds). Knowledge, information and development: an African perspective. Pietermaritzburg, School of Human and Social Studies, pp. v-vii. 
Underwood, P. 2002. "South Africa: a case study in development through information literacy". White paper prepared for UNESCO, the US National Commission on Libraries and Information Science, and the National Forum on Information Literacy, for use at the Information Literacy Meeting of Experts, Prague, Czech Republic.

http://www.nclis.gov.libinter/infolitconfandmeet/papers/underwoodfullpaper.pdf. Accessed 23 June 2010.

United Nations University. 2009. Revitalizing higher education in sub-Saharan Africa: United Nations University Project report. http://www.unu.edu/africa/files/UNU_RevitalizingHigherEducation.pdf. Accessed 22 July 2010.

Van Vuren, A.J. and Henning, J.C. 2001. User-education in a flexible learning environment: an opportunity to stay relevant in the 21 st century. South African journal of library and information science 67 (2): 79-85.

Viljoen, R. 2005. University of Namibia library information literacy training: a case study. In: Kiondo, E. and Msuya, J. (eds) User information literacy: case studies from university library programmes in SCANUL - ECS region. UK/Tanzania: INASP, pp 105-122.

Virkus, S. 2003. Information literacy in Europe: a literature review. Information research 8 (4): http://informationr.net/ir/8-4/paper159.html. Accessed 20 July 2010

Warmkessel M. M. and McCade, J.M. 1997. Integrating information literacy into the curriculum Research strategies 15 (2): 80-88.

Webber, S. and Johnston, B. 2000. Conceptions of information literacy: new perspectives and implications. Journal of information science 26 (6): 381-397.

Wema, E. and Hepworth, M. 2007. An evaluation of an information training initiative at the university of Dar-Es-Salaam. Journal of information literacy 1

(1): 1-12. http://ojs.lboro.ac.uk/ojs/index.php/JIL/article/view/RA-V1-I1-20071/2 Accessed 2 August 2010.

Whitehead, M.J. and Quinlan, C.A. 2002. Canada: an information literacy case study. White paper prepared for UNESCO, the US National Commission on Libraries and Information Science, and the National Forum on Information 
Literacy, for use at the Information Literacy Meeting of Experts, Prague, Czech Republic. http://www.nclis.gov/libinter/infolitconfandmeet/papers/quinlanfullpaper.pdf Accessed 2 July 2010.

Zwimpfer, L. 2006. Information literacy for all: an education challenge. In: Longworth, E. (ed). UNESCO Information for all programme: IFAP Report 2004/2005. Paris: UNESCO. pp.17-19. http://www.UNESCO.org/webworld/ifap Accessed 1 June 2006. 